
НАВЧАННЯЗАСОБАМИІНФОРМАЦЙНО-КОМУНІКАЦЙНИХТЕХНОЛОГІЙ

of physical education of visually impaired children]. Young sports science of Ukraine. Issue 7. Vol. 1. pp. 370-372. [in Ukrainian].

13. Pro vnesennia zmin do deiakykh zakoniv Ukrainy pro osvitu shchodo orhanizatsii inkliuzyvnoho navchannia : Zakon Ukrainy vid 05.06. 2014 r. [On amendments to some laws of Ukraine on education regarding the organization of inclusive education: Law of Ukraine of 05.06.2014]. [in Ukrainian].

14. Pro vnesennia zmin do zakonu Ukrainy "Pro osvitu" shchodo osoblyvostei dostupu osib z osoblyvymy osvitnimy potrebamy do osvitnikh posluh vid 23.05. 2017 r. [On Amendments to the Law of Ukraine "On Education" Regarding the Peculiarities of Access of Persons with Special Educational Needs to Educational Services" of 23.05. 2017]. [in Ukrainian].

15. Sitovskyi, A. M. (2008). Dyferentsiiovanyi pidkhid u fizychnomu vykhovanni pidlitkiv z riznymy tempamy biolohichnoho rozvytku (na prykladi shkoliariv 7-kh klasiv) [Differentiated approach in physical education of adolescents with different rates of biological development (on the example of 7 th grade students)]. Extended abstract of candidate's theasis. 20 p. [in Ukrainian].

16. Turchyk, I. (2003). Osoblyvosti fizychnoho vykhovannia shkoliariv Velykobrytanii [Features of physical education of schoolchildren in Great Britain]. Young sports science of Ukraine. Issue 7, Vol. 2. pp. 172-175. [in Ukrainian].

17. Turchyk, I. \& Shyian, O. (2004). Intehratsiia uchniv z osoblyvymy potrebamy u navchalnyi protses iz fizkulturnoi osvity (FKO) v Anhlii [Integration of students with special needs into the educational process in physical education (PE) in England]. Scientific notes of Ternopil State Pedagogical University. Series: Pedagogy. No.4. pp. 143 - 145. [in Ukrainian].

18. Turchyk, I. (2014). Shkilnyi sport yak sotsialnotsinnisna systema u pratsiakh zarubizhnykh fakhivtsiv [School sport as a social value system in the works of foreign experts]. Problems of modern pedagogical education. No.46. pp. 206 - 213. [in Ukrainian].

19. Chudnaya, R. V. (2000). Adaptivnoe fizicheskoe vospitanie [Adaptive physical education]. Scientific thought. Kyiv, 360 p. [in Russian].

Стаття надійшла до редакції 24.11.2020

УДК 373.091.016-057.87:004

DOI:

Іван Нищак, доктор педагогічних наук, дочент, професор кафедри технологічної та професійної освіти Дрогобицького державного педагогічного університету імені Івана Франка

Михайло Юрків, студент Дрогобиџького державного педагогічного університету імені Івана Франка

\title{
АКТИВІЗАЦІЯ НАВЧАЛЬНО-ПІЗНАВАЛЬНОЇ ДІЯЛЬНОСТІ УЧНІВ НА УРОКАХ ТРУДОВОГО НАВЧАННЯ ЗАСОБАМИ ІНФОРМАЦЙНО-КОМУНІКАЦЙНИХ ТЕХНОЛОГІЙ
}

У статті досліджено психолого-педагогічні основи використання інформаційно-комунікаційних технологій (IКT) в освітньому процесі, з’ясовано їх дидактичний потенціал для активізації навчальнопізнавальної діяльності учнів на уроках трудового навчання. Використання засобів IКТ у трудовій підготовиі школярів передбачає роботу з низкою сучасних програм комп 'ютерної графіки (Adobe Photoshop, CorelDRAW, Quark-XPress, 3D Studio MAX, “КОМПАC” та ін.), щуо стимулює в учнів інтерес до художньо-творчоі діяльності, сприяє активізації пізнавальних здібностей особистості.

Ключові слова: інформачійно-комунікачійні технологї̈; комп 'ютерна графіка; навчально-пізнавальна діяльність; програмний засіб; трудове навчання.

Puc. 5. Лim. 7.

Ivan Nyshchak, Doctor of Sciences (Pedagogy), Professor of the Technological and Vocational Education Department Drohobych Ivan Franko State Pedagogical University

Mykhailo Yurkiv, Student of Drohobych Ivan Franko State Pedagogical University

\section{ACTIVATION OF EDUCATIONALAND COGNITIVE ACTIVITY OF STUDENTS IN LESSONS OF LABOR TRAINING BY MEANS OF INFORMATION AND COMMUNICATION TECHNOLOGIES}

The article explores the psychological and pedagogical foundations of the use of information and communication technologies in the educational process, clarifies their didactic potential for activating the 


\section{АКТИВІЗАЦІЯ НАВЧАЛЬНО-ППЗНАВАЛЬНОӤ ДІЯЛЬНОСТІ УЧНІВ НА УРОКАХ ТРУДОВОГО НАВЧАННЯЗАСОБАМИ ІНФОРМАЦЙНО-КОМУНІКАЦІЙНИХТЕХНОЛОГЙ}

educational and cognitive activities of students in the lessons of labor training. It is established that the purposeful use of information and communication technologies in the education system leads to transformational changes in methods and organizational forms of learning, provides ample opportunities for varying the level of management of educational and cognitive activities of students, allows students to reflect on their own actions. Increasing the role of information and communication technologies in the education system leads to a reorientation of the educational process from the reproductive environment to stimulate creative activity of students, affects the methodological system of education at all levels (an educational goals, learning content, teaching methods, organizational forms).

The use of information and communication technologies in labor training lessons involves working with a number of modern computer graphics programs (Adobe Photoshop, CorelDRAW, Quark-XPress, 3D Studio MAX, “COMPAS", etc.). The use of Adobe Photoshop tools, including a set of graphic filters, allows stylization of any graphic images for different types of artistic and creative work of students, which provides a quick virtual model of the future product, selection of the necessary tools and manufacturing technologies. Such work stimulates the students' interest in artistic and creative activities, promotes the activation of cognitive abilities of the individual.

Important in the lessons of labor training is the use of computer-aided design system "COMPAS", which accelerates the process of designing future products of students, allows the creation of their three-dimensional models, provides the ability to predict the results of project activities.

Keywords: information and communication technologies; computer graphics; educational and cognitive activities; software; work training.

$\Pi$ остановка наукової проблеми та їі значення. Характерною ознакою сучасного етапу суспільного розвитку $\epsilon$ невпинне зростання обсягу інформації та впровадження інформаційних ідей, засобів і технологій практично у всі галузі людської діяльності. Швидкий розвиток технічних i програмних засобів інформаційно-комунікаційних технологій (ІКТ) забезпечує реальні можливості для їх широкого використання у системі освіти, що відкриває нові перспективи для представлення, сприймання, засвоєння, зберігання та передавання навчальної інформації.

Упровадження інформаційно-комунікаційних технологій до системи освіти України та формування єдиного інформаційно-освітнього простору - пріоритетні напрями інформаційного суспільства [1]. Тому перед системою загальної шкільної освіти постає вкрай важливе завдання, спрямоване на формування нових знань й умінь учнів в умовах інформатизації усіх галузей виробництва, а відтак актуалізується потреба розробки і впровадження нових технологій і засобів навчання.

Нові освітні технології, нестандартні форми проведення занять сприяють розвиткові інтересу учнів до процесу навчання, суттєво підвищують пізнавальну активність, уможливлюють поглиблення самостійної навчально-пізнавальної діяльності [2]. Застосування ІКТ в освітньому процесі не лише полегшує сприйняття учнями навчального матеріалу, але й підвищує інтенсивність, ефективність уроку, забезпечує розвиток особистості школярів, формує інформаційну культуру підростаючого покоління.

Актуальність дослідження зумовлена підвищенням інтересу до інформаційнокомунікаційних технологій, які забезпечують принципово нові можливості для активізації навчально-пізнавальної діяльності учнів на уроках трудового навчання.

Аналіз досліджень 3 проблеми. Проблема активізації навчально-пізнавальної діяльності школярів, зокрема на уроках трудового навчання, знайшла широке висвітлення у працях багатьох вітчизняних та зарубіжних учених (П. Атутов, О. Коберник, А. Линда, В. Мадзігон, Л. Оршанський, В. Стешенко, Г. Терещук, Д. Тхоржевський та ін.). Теоретико-методологічні основи комп'ютерноорієнтованого навчання стали предметом наукового пошуку Н. Морзе, М. Жалдака, Ю. Жука, В. Жукової, Г. Козлакової, Ю. Рамського та ін. Дослідженню дидактичних можливостей інформаційно-комунікаційних технологій в процесі трудової підготовки учнів присвячені наукові праці О. Ващук, Р. Гуревича, I. Петрицина, В. Сидоренка та ін.

Мета статті - дослідити шляхи і можливості активізації навчально-пізнавальної діяльності учнів на уроках трудового навчання засобами інформаційно-комунікаційних технологій.

Виклад основного матеріалу. Уперше ідея застосування комп'ютера в освітньому процесі 3'явилася в рамках концепції програмованого навчання, коли цифрова техніка розглядалася як більш надійна й досконала, порівняно з уже використовуваними навчальними машинами, як засіб реалізації програмованого навчання. Твердження, що комп'ютерна техніка уможливлює принципові зміни у системі освіти, приводить до перебудови змісту навчання, методів та форм педагогічної взаємодії, значно розширює коло навчальних задач, дає змогу забезпечити принципово нове навчальне середовище і можливість діалогізувати процес навчання. 


\section{АКТИВІЗАЦІЯ НАВЧАЛЬНО-ПІЗНАВАЛЬНОЇ ДІЯЛЬНОСТІ УЧНІВ НА УРОКАХ ТРУДОВОГО}

НАВЧАННЯЗАСОБАМИІНФОРМАЦЙНО-КОМУНІКАЦЙНИХ ТЕХНОЛОГЙ

Сучасні засоби інформаційно-комунікаційних технологій володіють значним дидактичним потенціалом для підвищення ефективності освітнього процесу, що передбачає $[3 ; 5 ; 6]$ :

- новизну роботи з цифровою технікою, що забезпечує підвищення пізнавального інтересу школярів, посилення мотивації до навчання;

- використання кольору, графіки, мультиплікації, музики, голосового супроводу й, особливо, відеотехніки, що значно розширює можливості подання навчальної інформації;

- збільшення кількості типів навчальних задач, зокрема на моделювання різноманітних навчально-виробничих ситуацій, пошук та усунення несправностей чи невідповідностей, планування, пошук оптимальної стратегії розв'язування та ін.;

- можливість залучення школярів до дослідницької діяльності, організації віртуальних навчальних експериментів;

- можливість інтеграції знань, що дає змогу здійснити ефективне взаємопроникнення змісту шкільних навчальних предметів;

- звільнення школярів від трудомісткої рутинної роботи (зокрема численних обрахунків та графічних побудов), полегшення редагування текстів, внесення відповідних виправлень та ін.;

- доступ учнів до раніше недоступної інформації, миттєве одержання необхідних відомостей;

- активне включення учнів до освітнього процесу, можливість зосереджувати увагу на найважливіших аспектах матеріалу, що вивчається;

- організацію індивідуалізованого навчання на основі моделі учня, яка враховує історію його учіння, особливості психічних процесів (пам'яті, мислення, уяви та ін.), допомагає учневі вибирати найбільш оптимальну траєкторію навчання, одержати необхідну допомогу.

До сучасних комп’ютеризованих програмних засобів освітнього призначення відносять: комп’ютерні навчальні середовища, в тому числі мережеві; імітатори експериментів; інформаційномоделювальні програми; міжпредметні інформаційні середовища; інтелектуальні навчальні системи; бази даних (знань); електронні підручники, посібники; комп'ютеризовані бібліотеки, архіви, довідники та енциклопедії; системи підтримки мультимедійних on-line конференцій та ін. [2].

Упровадження IКT до системи освіти приводить до трансформаційних змін у методах й організаційних формах навчання. Застосування комп'ютера дає змогу “включити” школяра в процес мислення, перебіг якого може моделюватися спеціальною комп'ютерною навчальною програмою, тобто засвоєння навчального матеріалу здійснюється у процесі опосередкованого комп'ютером спілкування. Системна взаємодія у комп'ютерних навчальних програмах з варіативністю “діалогу” привчає школярів адаптовуватися до необхідності вибору відповідних альтернатив, попередньо оцінивши їх раціональність і доцільність. Опосередковане комп'ютером спілкування розкриває значні можливості для стимулювання внутрішнього діалогу суб'єктів навчання [4].

Використання IКТ забезпечує варіювання рівня управління навчальною діяльністю учнів, що уможливлює ефективне використання різного типу знань, надаючи школярам змогу користуватися будь-якими довідниковими й ілюстративними ресурсами (пояснення, цитати, довідки, рекомендації та ін.).

Застосування інформаційно-комунікаційних технологій розширює можливості представлення навчально-пізнавальної інформації, що уможливлює знівелювати один 3 найголовніших чинників негативного ставлення до навчання неуспіх, зумовлений нерозумінням учнями сутності проблем, суттєвими прогалинами у знаннях. За допомогою IКТ можна активно залучати школярів до пошуково-дослідницької діяльності, розширюючи типи навчальних задач та підвищуючи в учнів мотивацію до навчання. При цьому з'являється можливість оцінити ефективність будь-якого розв'язку задачі, зокрема і нетипового, з'ясувати доцільність обраної стратегії пошукової діяльності та забезпечувати постійний контроль за її перебігом.

Застосування інформаційно-комунікаційних технологій уможливлює формуванню в учнів рефлексії власних дій, оскільки з'являється можливість візуально споглядати одержаний результат навчальної діяльності. Спеціальні програми-тести дозволяють більш точно оцінювати такі характеристики особистості, як тип мотивації, ступінь адекватності, рівень самооцінки та ін. [6].

Підвищення ролі ІКТ в системі освіти зумовлює переорієнтацію освітнього процесу 3 репродуктивного середовища на стимулювання творчої активності школярів. Творчого, евристичного характеру мислення учнів набуває при роботі з різноманітним, багатоплановим навчальним матеріалом, який методично обгрунтовано подають вчителі в усній, письмовій та електронній формах, активізуючи при цьому якомога більшу кількість сенсомоторних 
АКТИВІЗАЦІЯ НАВЧАЛЬНО-ПІЗНАВАЛЬНОЇ ДІЯЛЬНОСТІ УЧНІВ НА УРОКАХ ТРУДОВОГО НАВЧАННЯ ЗАСОБАМИІНФОРМАЦЙНО-КОМУНІКАЦЙНИХ ТЕХНОЛОГІЙ



Рис. 1. Головне вікно Adobe Photoshop, що містить вихідне графічне зображення собаки

механізмів психіки школяра, що, своєю чергою, сприяє поступовому виробленню стійких навичок вмілого застосування здобутих знань у проблемних ситуаціях. Комп'ютеризовані засоби при цьому стають не лише технічним знаряддям освітнього процесу - їх використання формує новий інтелектуальний фон, нову операційну обстановку, що органічно i природно використовується учнем для свого розвитку в школі та вдома [7].

Системне впровадження засобів IКТ в освітній процес здійснює вплив на усю методичну систему навчання на всіх її рівнях, зокрема [1]:

- на рівні освітніх цілей - 3'являється нова мета, пов'язана 3 підготовкою учнів до життєдіяльності в інформаційному суспільстві;

- на рівні змісту навчання - актуалізується потреба включення в курс шкільних навчальних дисциплін нового змісту практично-орієнтованого характеру та перегляду застарілого навчального матеріалу;

- на рівні методів навчання - уможливлюється ширше використання інноваційних, інтерактивних методів педагогічної взаємодії;

- на рівні організаційних форм - забезпечується використання нових форм начальної діяльності учнів, зокрема групових та індивідуальнодиференційованих.

Використання інформаційно-комунікаційних технологій на уроках трудового навчання передбачає роботу з низкою сучасних програм комп'ютер-ної графіки і дизайну (Adobe Photoshop, CorelDRAW, Quark-XPress, 3D studio MAX, "КОМПАС" та ін.).

Доцільним вбачається використання графічного редактора Adobe Photoshop на уроках трудового навчання. Застосування інструментальних засобів Adobe Photoshop, зокрема набору графічних фільтрів, уможливлює швидку й ефективну стилізацію будь-яких графічних зображень під різні види художньотворчих робіт школярів (вишивку, аплікацію, гравірування, ниткографію, випалювання, карбування та ін.). На рис. 1 представлено головне вікно Adobe Photoshop, що містить вихідне графічне зображення собаки, завантажене 3 мережі Інтернет або іншого цифрового пристрою (фотокамери, смартфону, сканера та ін.).

Виконання команди Фильтр $\rightarrow$ Texture $\rightarrow$ Patchwork дає змогу активувати відповідний фільтр, 3 допомогою якого можна ство-рити стилізацію графічного зображення під вишивку "хрестиком" або аплікацію клаптиками кольорового паперу чи тканини (рис. 2).

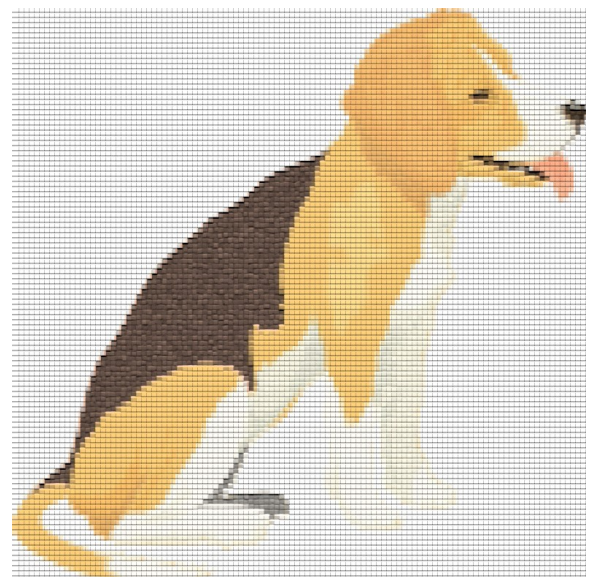

Рис. 2. Результат роботи графічного фільтра "Patchwork"

Використання графічного фільтра “Mosaic Tiles” (послідовність команд Фильтр $\rightarrow$ Texture $\rightarrow$ Mosaic Tiles) уможливить стилізацію графічного зображення під мозаїку (рис. $3, a$ ); графічний фільтр “Випуклий рисунок” (послідовність команд Фильтр $\rightarrow$ Texture $\rightarrow$ Випуклий рисунок) дасть змогу стилізувати графічне зображення під техніку карбування (рис. рис. 3,6$)$; результат роботи графічного фільтра "Вивести контур” (послідовність команд Фільтр $\rightarrow$ Texture $\rightarrow$ Вивести контур) забезпечить одержання контуру графічного зображення для випилювання лобзиком та подальшого оздоблення технікою випалювання (рис. 3, 6).

Необхідним вбачаємо використання графічних можливостей Adobe Photoshop для стилізації художнього оздоблення деревини, зокрема різьблення. Завдяки спеціальним засобам роботи 

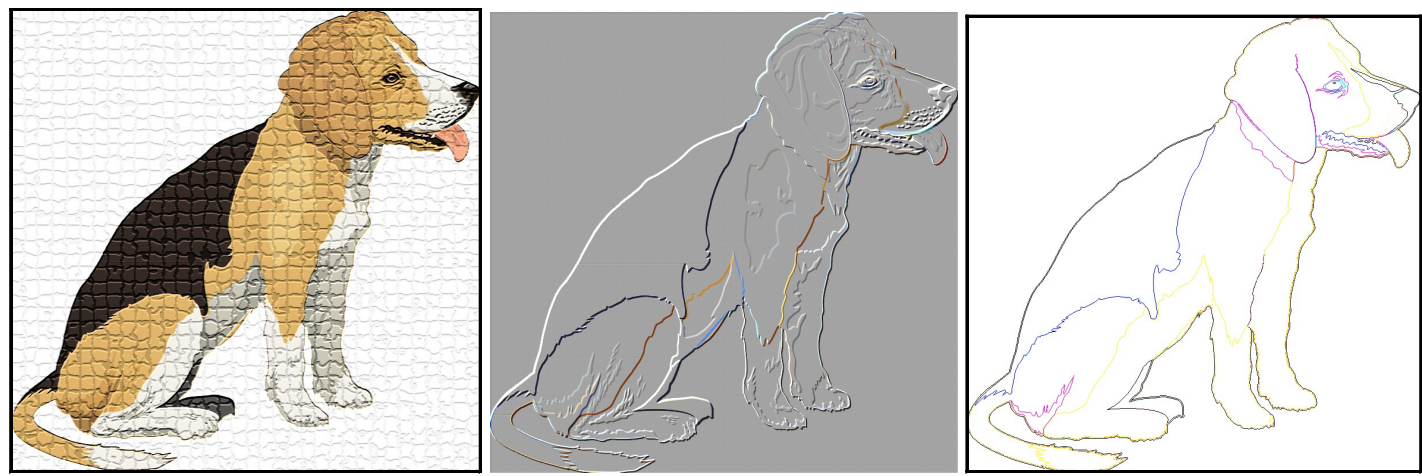

Рис. 3. Результат стилізації графічного зображення під різні види художньо-творчих робіт учнів 3 допомогою графічних фільтрів Adobe Photoshop: a) стилізація під мозаїку;

б) стилізація під карбування;

в) стилізація під випилювання лобзиком та наступне випалювання

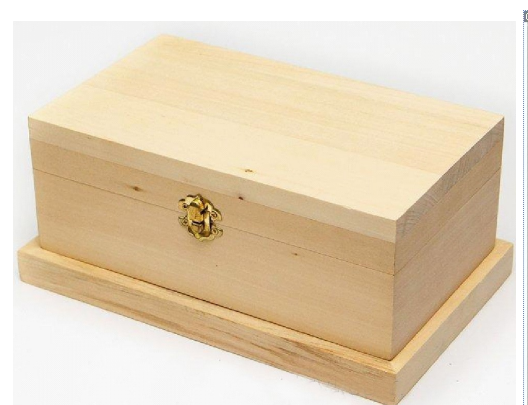

a)

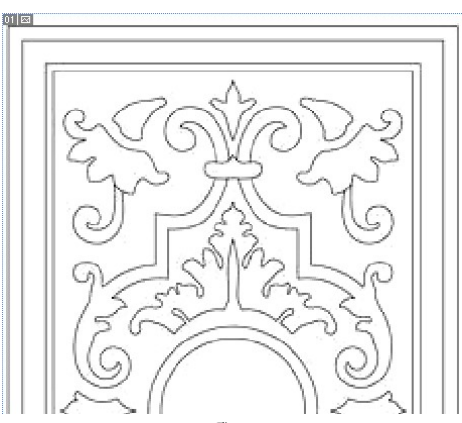

б)

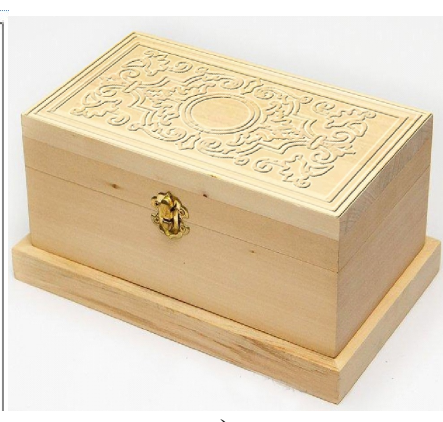

B)

Рис. 4. Стилізація кришки скриньки під техніку різьблення: а - зображення скриньки; б - фрагмент орнаменту; в - результат можливого оздоблення кришки скриньки

з виділеними фрагментами об'єктів та шарами зображень можна досягти надзвичайно реалістичного результату. Наприклад, перед школярами стоїть завдання оздобити (різьбленням) кришку скриньки для зберігання коштовностей. Сфотографувавши виріб (заготовку), учні завантажують відповідне зображення (фотографію) у графічний редактор Adobe Photoshop (рис. 4, a). Паралельно здійснюється вибір можливого варіанту візерунка (орнаменту) оздоблення кришки, який також оцифровується (сканується, фотографується) та завантажується у графічний редактор (рис. 4, б). Перевівши орнамент різьблення у контур виділення, та взявши за основу фотографію кришки скриньки, створюється новий шар зображення, який за допомогою спеціальних ефектів імітує різьблену поверхню (рис. 4, в).

Використання Adobe Photoshop для стилізації різних видів художньо-творчої діяльності школярів забезпечує швидке одержання відповідної віртуальної моделі майбутнього виробу, вибір необхідних інструментів і технологій виготовлення. Така робота стимулює в учнів інтерес до художньо-творчої діяльності, сприяє активізації пізнавальних здібностей.

Важливе значення для попереднього представлення форми і розмірів майбутніх виробів учнів на уроках трудового навчання має використання системи автоматизованого проєктування (САПР) “КОМПАС”, що дає змогу створювати відповідні тривимірні моделі об'єктів праці, видозмінювати їх форму, розміри та просторове положення.

Моделювання майбутніх об’єктів практичної діяльності учнів з використанням інструментальних засобів САПР “КОМПАС” розширює можливості школярів для творчості, оскільки за короткий проміжок часу можна змоделювати різні варіанти конструкції виробу, порівняти переваги і недоліки кожного з них відповідно до технологічних, ергономічних, економічних та експлуатаційних вимог, обгрунтувати й обрати найоптимальніший 3 них, а найголовніше, - при цьому відсутні будьякі ризики, пов'язані 3 виготовленням невідповідного (недосконалого) об'єкта праці, нераціональним використанням матеріалів, зношуванням інструментів й обладнання тощо. 


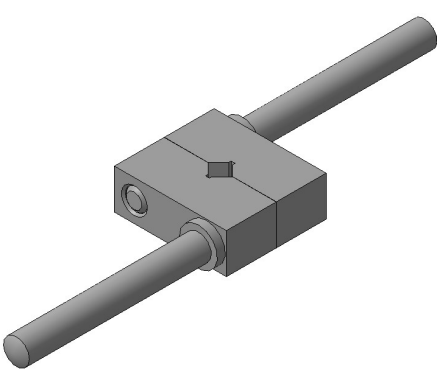

a)

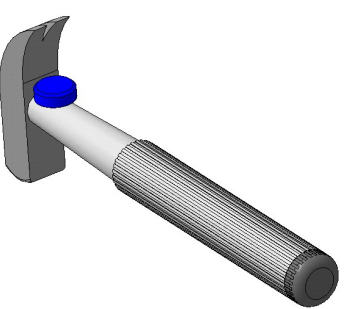

б)

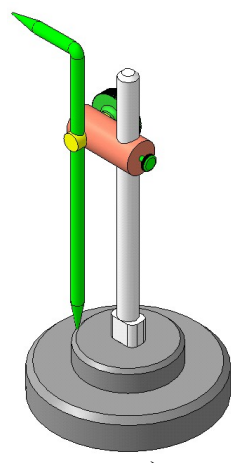

B)

Рис. 5. Тривимірні моделі технічних пристроїв: a - вороток; б - молоток комбінований; в - рейсмус

На рис. 5 представлено тривимірні моделі технічних пристроїв (зразки учнівських робіт), створених у середовищі САПР “КОМПАС".

Висновки. Таким чином, можна стверджувати, що сучасні засоби інформаційно-комунікаційних технологій володіють значним дидактичним потенціалом для підвищення ефективності освітнього процесу, зокрема активізації навчальнопізнавальної діяльності учнів на уроках трудового навчання.

Застосування засобів IКТ (цифрової техніки, відповідного програмного забезпечення) уможливлює віртуальну стилізацію будь-яких графічних зображень під різні види художньотворчих робіт школярів, прискорює процес проєктування об'єктів праці, забезпечує прогнозування результатів проєктної діяльності, що стимулює в учнів інтерес до художньої творчості, сприяє активізації пізнавальних здібностей особистості.

\section{ЛІТЕРАТУРА}

1. Гершунский Б.С. Компьютеризация в сфере образования: проблемы и перспективы. Москва: Педагогика, 1987.263 с.

2. Гуревич Р.С., Кадемія М.Ю., Шевченко Л.С. Інформаційні технології навчання: інноваційний підхід. Вінниця: ТОВ фірма “Планер”, 2012.348 с.

3. Лапінський В.В. Дидактичні вимоги до комп'ютерно-орієнтованих засобів навчання. Нові технології навчання: наук.-метод. зб. / кол. авт. Київ: Наук.-метод. центр вищої освіти, 2004. С. 104 - 107.

4. Машбиц Е.И., Комиссарова Е.Ю. Диалог в обучающей системе. Киев: Выща шк., 1989. 84 с.

5. Нищак І.Д. Дидактичні можливості інформаційних технологій навчання у процесі інженерно-графічної підготовки студентів. Вісник Черкаського ун-ту. 2015. №26 (359). C. $11-17$.
6. Нищак І.Д. Інформаційні технології як засіб розвитку технічного мислення (методика використання на заняттях $з$ креслення): навч.-метод. посіб. Дрогобич: РВВ ДДПУ ім. І. Франка, 2008. 108 с.

7. Тихомиров О.К., Бабанин Л.Н. ЭВМ и новые проблемы психологи. Москва: из-во Моск. ун-та, 1986. 204 с.

\section{REFERENCES}

1. Gershunskiy, B.S. (1987). Kompyuterizatsiya v sfere obrazovaniya: problemyi i perspektivyi [Computerization in education: problems and prospects]. Moscov, $263 \mathrm{p}$. [in Russian].

2. Hurevych, R.S., Kademiia, M.Iu. \& Shevchenko, L.S. (2012). Informatsiini tekhnolohii navchannia: innovatsiinyi pidkhid [Information learning technologies: an innovative approach]. Vinnytsia, 348 p. [in Ukrainian].

3. Lapinskyi, V.V. (2004). Dydaktychni vymohy do kompiuterno-oriientovanykh zasobiv navchannia [Didactic requirements for computer-based teaching aids]. New learning technologies: scientific method. collec. Kyiv, pp. 104 - 107. [in Ukrainian].

4. Mashbits, E.I. \& Komissarova, E.Yu. (1989). Dialog $\mathrm{v}$ obuchayuschey sisteme [Dialogue in the training system]. Kiev, 84 p. [in Russian].

5. Nyshchak, I.D. (2015). Dydaktychni mozhlyvosti informatsiinykh tekhnolohii navchannia u protsesi inzhenerno-hrafichnoi pidhotovky studentiv [Didactic possibilities of information technologies of education in the process of engineering and graphic training of students]. Bulletin of Cherkasy University. No. 26 (359). pp. $11-17$. [in Ukrainian].

6. Nyshchak, I.D. (2008). Informatsiini tekhnolohii yak zasib rozvytku tekhnichnoho myslennia (metodyka vykorystannia na zaniattiakh z kreslennia) [Information technology as a means of developing technical thinking (methods of use in drawing lessons)]. Drohobych, $108 \mathrm{p}$. [in Ukrainian].

7. Tihomirov, O.K. \& Babanin, L.N. (1986). EVM i novyie problemyi psihologi [Computer and new problems psychologists]. Moscov, 204 p. [in Russian].

Стаття надійшла до редакції 09.12.2020 